\title{
Odnowienie doktoratu profesor Wandy Nowakowskiej
}

W

dniach 26 i 27 listopada 2015 r. w Pałacu Biedermanna przy ul. Franciszkańskiej 1/5 odbyło się odnowienie doktoratów sześciorga uczonych polskich, którzy swoją karierę naukowa rozpoczynali na Uniwersytecie Łódzkim. Święto powiązane było z uroczystymi posiedzeniami Senatu UŁ.

Odnowienie doktoratu to forma docenienia badaczy, którzy w wyjątkowy sposób zasłużyli się dla życia naukowego nie tylko swoim dorobkiem, lecz także postawą i charyzmą. To właśnie oni po półwieczu od otrzymania stopnia doktora zostali uhonorowani uroczystym odnowieniem pierwszego stopnia naukowego. W ten sposób społeczność akademicka oddała hołd profesorom, którzy dzięki swojej działalności zyskali w jej oczach wysokie uznanie. Taka formę wyróżnienia osób, które uzyskały stopień doktora na Uniwersytecie Łódzkim przed pięćdziesięcioma laty i w sposób szczególny zasłużyły się dla nauki lub kultury polskiej, ustanowił Senat UŁ w dniu 27 marca 2000 r.

Dnia 26 listopada 2015 r. odbyło się spotkanie poświęcone trójce naukowców, podczas którego nastapiło odnowienie trzech doktoratów: profesor Wandy Nowakowskiej (historyka sztuki), profesor Adeli Styczyńskiej (anglistki) i profesora Jacka Kolbuszewskiego (polonisty).

Dla historyków sztuki i historyków najbardziej wzruszająca była czwartkowa uroczystość odnowienia doktoratu profesor Wandy Nowakowskiej, która przez wiele lat zwiazana była z Wydziałem Filozoficzno-Historycznym UŁ. Na spotkanie w Sali Kominkowej Pałacu Biedermanna oprócz członków senatu przybyło wielu gości. Jako członek senatu, ale i badacz zaprzyjaźniony z profesor Nowakowska, w tych uroczystościach brał udział dziekan Wydziału Filozoficzno-Historycznego, prof. Zbigniew Anusik. Reprezentowane były 
wszystkie instytuty wydziału oraz (najliczniej) Katedra Historii Sztuki, której Pani Profesor była założycielką. Obecni byli dwaj kierownicy Katedry Historii Sztuki: obecny - prof. Krzysztof Stefański i poprzedni - prof. Grzegorz Sztabiński. Przybyli m.in. zaprzyjaźnieni z jubilatka prof. Alicja Szymczak, prof. Jan Szymczak (historycy), Aldona Pobojewska (filozof), prof. Leszek Kajzer i dr hab. Anna Marciniak-Kajzer (archeolodzy). Katedrę Historii Sztuki reprezentowali m.in. dr hab. Aneta Pawłowska, dr hab. Piotr Gryglewski, dr Irmina Gadowska, dr Julia Sowińska, dr Paulina Sztabińska, dr Ewa Kubiak. Większość $z$ nich to wychowankowie profesor Nowakowskiej - studenci, magistranci lub doktoranci. Całe wydarzenie uwieczniał na fotografiach mgr Janusz Frenkel.

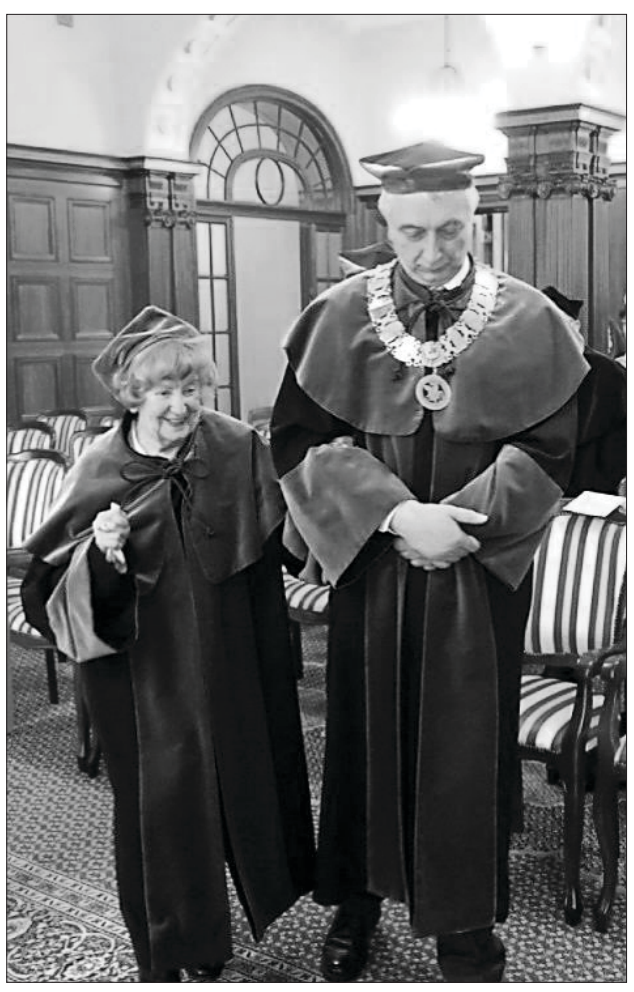

1. Profesor Wanda Nowakowska i Dziekan Wydziału Filozoficzno-Historycznego profesor Zbigniew Anusik w czasie uroczystości odnowienia doktoratu w Pałacu Biedermanna w dniu 26 listopada 2015 r.

Postać Wandy Nowakowskiej, jej ogromne zasługi na polu organizacji życia akademickiego i interesujacy dorobek naukowy przedstawił prof. Grzegorz Sztabiński. Po krótkiej i wzruszajacej przemowie uhonorowanej odebrała ona dyplom $z$ rak prof. Bogdana Gregora, prorektora UŁ do spraw ekonomicznych. Następnie wszyscy zebrani gratulowali profesor Nowakowskiej i udali się na poczęstunek do Sali Kolebkowej.

Warto w tym miejscu przybliżyć wizerunek profesor Wandy Nowakowskiej $z$ kilkoma faktami z życia badaczki ${ }^{1}$. Urodziła się w 1929 r. w Łodzi. W latach 1948-1952 studiowała psychologię i historię sztuki na Wydziale Humanistycznym Uniwersytetu Łódzkiego. Początkowo podjęła studia psychologiczne, jednak uczęszczała też na wykłady prof. prof. Tadeusza Kotarbińskiego,

${ }^{1} \mathrm{Z}$ noty biograficznej przygotowanej przez prof. Grzegorza Sztabińskiego i zaprezentowanej podczas uroczystości. 
Marii i Stanisława Ossowskich, Stefanii Skwarczyńskiej i Mieczysława Wallisa. Przyczyniło się to do zmiany kierunku studiów i koncentracji na zagadnieniach estetyki i historii sztuki. Rozprawę magisterska nt. Teoria wyrazu u Leonarda da Vinci napisała pod kierunkiem prof. M. Wallisa, uzyskując tytuł magistra w zakresie estetyki w roku 1952.

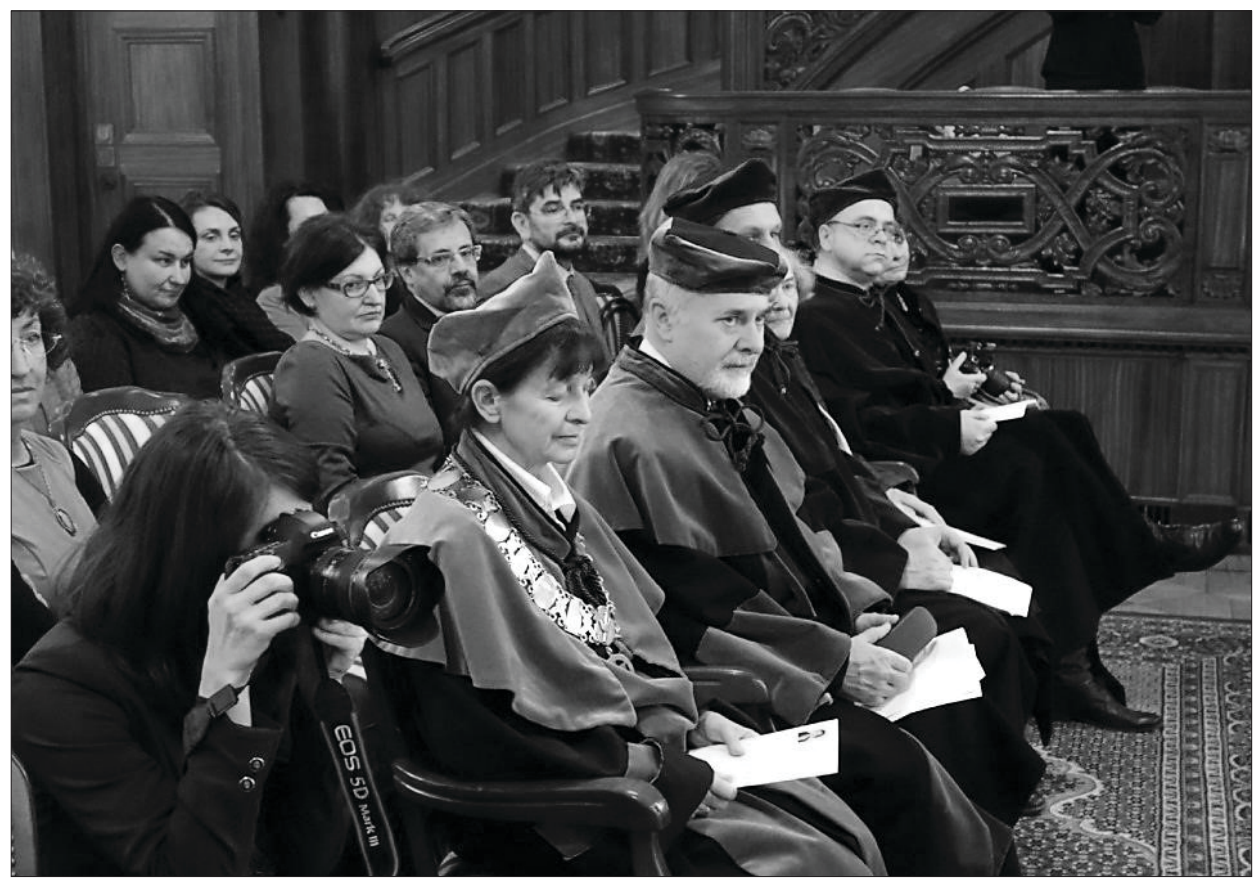

2. Goście zebrani w czasie uroczystości odnowienia doktoratu profesor Wandy Nowakowskiej w Sali Kominkowej Pałacu Biedermanna w dniu 26 listopada 2015 r.

Pracę zawodową rozpoczęła w Dziale Oświatowym Muzeum Sztuki w Łodzi. Następnie w latach 1956-1960 pełniła funkcję kierownika Działu Popularyzacji Wiedzy i Działu Wydawnictw w Łódzkim Towarzystwie Naukowym. W 1959 r. rozpoczęła prowadzenie zajęć dydaktycznych $z$ historii sztuki na wydziałach: Operatorskim, Reżyserskim i Aktorskim Państwowej Wyższej Szkoły Teatralnej i Filmowej w Łodzi, w Państwowej Wyższej Szkole Sztuk Plastycznych i Wyższej Szkole Muzycznej w Łodzi. Równocześnie zajmowała się działalnością naukowa, publikując artykuły i przygotowując rozprawę doktorska nt. Koncepcja krytyki artystycznej Stanisława Witkiewicza, również pod kierunkiem prof. M. Wallisa. W formie 
książkowej, pt. Stanisław Witkiewicz-teoretyk sztuki, monografia ta ukazała się w wydawnictwie Ossolineum we Wrocławiu w 1970 r.

Obrona pracy doktorskiej profesor Wandy Nowakowskiej odbyła się 30 września 1965 r. na Wydziale Filozoficzno-Historycznym UŁ. W tym samym roku podjęła pracę na Uniwersytecie Łódzkim w Katedrze Filozofii. W roku 1975 w łódzkiej uczelni został powołany Zakład Historii Sztuki. Przejście do niego umożliwiło W. Nowakowskiej pełne skoncentrowanie się na wybranej dziedzinie. Nominacje na jego kierownika otrzymała w 1980 r. Nie rezygnowała jednak z zainteresowań estetycznych. Od roku 1972 wchodziła w skład Komitetu Redakcyjnego „Studiów Estetycznych”.

Tematem jej rozprawy habilitacyjnej była Narodowa funkcja sztuki $w$ polskiej krytyce artystycznej lat 1863-1890. Została ona opublikowana przez Wydawnictwo Uniwersytetu Łódzkiego w roku 1981. Kolokwium habilitacyjne odbyło się 3 listopada 1983 r. na Wydziale Filozoficzno-Historycznym Uniwersytetu Jagiellońskiego. Stanowisko docenta na Uniwersytecie Łódzkim uzyskała w roku 1984. Nominację na profesora nadzwyczajnego UŁ otrzymała sześć lat później, a w 2000 r. uzyskała tytuł profesora.

Katedra Historii Sztuki i związany z nią kierunek studiów utworzono na Uniwersytecie Łódzkim $z$ chwila powstania uczelni w $1945 \mathrm{r}$. W pierwszym okresie jej dziejów kierowali nia prof. Wacław Husarski i prof. Mieczysław Wallis. Studia magisterskie w zakresie historii sztuki na UŁ zostały zlikwidowane w 1952 r. Zakład Historii Sztuki UŁ ponownie otworzono w 1975 r. Kierowała nim Wanda Nowakowska (wówczas doktor), prowadząc wykłady dla innych kierunków studiów. Ważnym i przełomowym momentem był rok 1992 . Ówczesny rektor Uniwersytetu Łódzkiego, prof. Michał Seweryński, podją decyzję o reaktywowaniu kierunku studiów historia sztuki. Zakładem, a od 1998 r. Katedra Historii Sztuki UŁ kierowała profesor Wanda Nowakowska. Powstanie studiów magisterskich z zakresu historii sztuki było spełnieniem wieloletnich pragnień i starań Wandy Nowakowskiej. W 1995 r. jej zasługi uhonorowane zostały Medalem Jubileuszowym 50-lecia Uniwersytetu Łódzkiego. Profesor Wanda Nowakowska jest autorka sześciu książek i ponad 70 artykułów naukowych.

Ewa Kubiak UNIWERSYTET ŁÓDZKI*

* Wydział Filozoficzno-Historyczny, Katedra Historii Sztuki. 